\title{
Large Flock of Western Tanagers
}

Mr. Charles A. Southey of Young reported to us on January 19, 1964, that he had observed a large flock of Western Tanagers late in the summer of 1963 at Little Manitou Lake within the parkland in south-central Saskatchewan. He was moved to submit this report by the account of Western Tanagers in the December, 1963, Blue Jay. Mr. Southey writes: "... for the first time in my life I saw a flock of Western Tanagers in this district. I spend my summers at a cottage on the south shore of Little Manitou Lake ... have always noted any unusual birds - and have not seen tanagers of any variety there in over half a century. Shortly after... [July 19] we received visitors we did not want, to wit-the leaf-eating poplar 'bug' [apparently the Aspen leaf beetle Chrysomela crotchi Brown 1. They played havoc with all the younger poplars and the birds seemed to avoid the stripped treesbut on August 14 a flock of about 26 Western Tanagers flew into the poplars and commenced to devour the 'bugs.' They stayed around for three days so we had plenty of opportunity to observe them. No other bird was ever observed eating these bugs."

In response to a query from the editors $\mathrm{M}:$. Southey added (February 5) that although the flock was "spread out a lot and generally on the move" and hence was difficult to count, there appeared to be $\mathbf{2 6}$ birds. He stated that of this group only three were identifiable as adult males; five others could be identified as adults; the balance appeared to be young birds. [The male tanager assumes a female-like plumage in the late summer molt, gradually losing its red head plumage.] "No doubt if they had been in spring plumage the crimson on the head of the males would have been easier to see. I am 75 years-my sight is not as good as it used to be but I am absolutely sure of them being Western Tanagers..."

As indicated in a recent brief report (Blue Jay, 1963, pp. 136-7) there are practically no previous records of the Western Tanager in southern Saskatchewan in the summer or fall. Available documented records are: May 13 (1963, Broadview), May 18 (1962, Regina), May 21 (1961, Estevan), May 22 (1962 Moose Jaw), May
25 (1935, Cochin), and May 28 (1962, Moose Jaw). According to reports in A. C. Bent's summary (1958. Life histories of North American blackbirds, orioles, tanagers, and allies. U.S. Natl. Mus. Bull. 211) the usual route of their spring migration is from the west coast across the mountains into Alberta, rather than a direct route northward across the plains. The scarcity of fall records may be attributed to a late summer movement in the reverse path, from the Canadian Life Zone region of Saskatchewan, in which they breed, westward into Alberta and across the mountains. The increase in spring records in Saskatchewan may be due to a shift in direction of movement possibly related to $a$ population increase. We wish to thank Lloyd O. T. Peterson (Head, Entomology Section, Tree Nursery, P.F.R.A., Indian Head) who kindly identified the insects in this report through further correspondence with Mr. Southey and Mr. K. R. Elliott (Forest Ento. Lab., Winnipeg). -The Editors.

\section{UNUSUAL OWL - LOON AERIAL COLLISION}

"Loon's radar not working"-was the lead on an item in the October 12, 1963 Leader-Post. "Man has always envied birds for an instinct that guides them safely through the air, but a Melville district farmer, Alf Litzenberger, has reason to believe their system is not so infallible after all. Summer-fallowing his land recently he came upon two birds lying side by side in a field. One, a loon with a long, pointed beak, had died from a broken neck, the other, an owl, had a gaping hole in its chest. The two had apparently collided in mid-air, the sharp beak of the loon piercing the chest of the owl."

Through a telephone call to $\mathrm{Mr}$. Litzenberger we learned that this observation was made about October 2; the part pants were apparently a Common Loon and a Great Horned Owl. At our request an attempt was made to recover the carcasses for further examination but they were missing and had evidently been carried off by some hungry predator.The Editors. 